\title{
Den personlige faktor Højre- og venstreorienterede vælgere foretrækker forskellige kandidatpersonligheder
}

\author{
Lasse Laustsen \\ Ph.d.-studerende, Institut for Statskundskab, Aarhus Universitet.
}

I den danske valglitteratur er betydningen af kandidaters personligheder ofte blevet nedtonet. Jeg argumenterer i denne artikel for, at denne konklusion måske bygger på, at man hidtil ikke har undersøgt, om forskellige kandidatpersonligheder foretrækkes på de to politiske fløje. På baggrund af et surveyeksperiment gennemført i Danmark viser jeg, at højre- og venstreorienterede individer foretrækker henholdsvis dominante og imødekommende kandidatpersonligheder.

\section{Introduktion}

I den brede offentlighed tillægges politikeres personligheder ofte væsentlig betydning for udfaldet af såvel folketings- som kommunalvalg. Et eksempel herpå er opmærksomheden mod centrale politikeres personlige og private forhold, som ikke mindst er blevet eksemplificeret ved Helle Thorning-Schmidts skatteforhold, Mette Frederiksens valg af skole for sine børn samt Lars Løkke Rasmussens rejse- og tøjudgifter. Foruden et skær af skandale og hykleri har eksemplerne også det til fælles, at de tegner et billede af de implicerede politikeres grundværdier og mere personlige forhold. Historier om politikernes personlige og private forhold kan således hjælpe vælgerne til at få et indblik i, hvordan toppolitikeres mere fundamentale personlighedsdispositioner ser ud. I forlængelse heraf synes det relevant at undersøge betydningen af politikeres personlighed ved at spørge $o m$, og i givet fald hvordan, vælgernes vurderinger af politikeres personlighed påvirker deres stemmeadfærd. Det er disse spørgsmål, som jeg her vil forsøge at besvare ved hjælp af et surveyeksperiment. Eksisterende forskning har hidtil undersøgt betydningen af politikeres personlighed ved hjælp af valgundersøgelser, som inkluderer respondenternes opfattelse af fremtrædende kandidater. I en dansk sammenhæng viser disse undersøgelser, at betydningen af kandidaters personlighed er tvivlsom og formentlig minimal (Andersen \& Borre 2003, Andersen \& Borre 2007, Hansen \& Andersen 2013). Dog stemmer ca. halvdelen af de danske vælgere personligt, når de står bag gardinet i stemmeboksen på valgdagen (Danmarks Statistik 2012, 53). Den internationale valglitteratur er da også lidt mere optimistisk med hensyn til effekterne af kandidatpersonlighed, om end resultaterne her dog også peger lidt i forskellige retninger (Hayes 2009, Funk 1999, Clark 2004, Jenssen \& Aalberg 2006, King 2002).

I denne artikel vil jeg argumentere for, at de forskelligartede og uklare resultater i den eksisterende litteratur kan have såvel en teoretisk som en metodisk årsag. Teoretisk overser den eksisterende litteratur, at vælgerne på højre- og venstrefløjen er væsentligt forskellige, og at de derfor kan forventes at foretrække forskellige kandidatpersonligheder. Metodisk har det med de hidtil benyttede survey designs ikke været muligt at undersøge betydningen af kandidatpersonlighed uafhængigt af kandidatens partifarve, politiske holdninger osv.

Jeg finder støtte til forventningen om, at vælgere på højre- og venstrefløjen foretrækker forskellige kandidatpersonligheder, i et surveyeksperiment udført blandt danske studerende. Mere præcist vurderes en fiktiv mandlig politiker mere positivt på højre- end på venstrefløjen, når han er beskrevet som en dominant person. Omvendt vurderes han mere positivt blandt eksperimentets venstre- end højreorienterede deltagere, når han er beskrevet som en imødekommende person. Dette resultat diskuteres afslutningsvist i forhold til den generelle betydning af kandidaters personlighed for valgresultater. Især giver resultatet anledning til at overveje betydningen af kandidatpersonlighed for konkurrencen internt mellem partier i samme blok og for konkurrencen mellem kandidater opstillet for samme parti. Intrablok- og intra- 
parti-konkurrence er helt centrale karakteristiska for et flerpartisystem som det danske, hvor alle partier opstiller en hel række kandidater. Imidlertid har den eksisterende valgforskning typisk overset netop denne betydning af kandidatpersonlighed.

\section{Hvad betyder kandidaters personlighed?}

Skal man tro den klassiske danske valgforskning, så er det ikke blandt faktorer knyttet til de politiske ledere, at man finder hovedforklaringen på udfaldet af folketingsvalg. Således skriver Andersen og Borre i forbindelse med 2001-valget, at "Også i Danmark betyder sympatien for partiet langt mere end sympatien for dets leder" (Andersen $\&$ Borre 2003, 363-364). Denne konklusion blødes der en smule op for ved det følgende valg i 2005, idet konklusionen da lyder: „Ledere gør altså en forskel. De gør det bare ikke alene, og det kan vare svart helt precist at sige hvilken" (Andersen \& Borre 2007, 305). Endelig konkluderes for det seneste folketingsvalg i 2011, at selvom effekterne af sympati for partilederne nok er små, så er de trods alt signifikante, til trods for at de "er testet under de svarest tankelige betingelser" (Hansen \& Andersen 2013, 204).

Også i den internationale valglitteratur peger resultaterne i forskellige retninger. Således tilskriver Donald E. Stokes kandidater en relativt vigtig rolle, idet han skriver, at "The fluctuations of electoral attitudes over these elections have to a remarkable degree focused on the candidates themselves" (Stokes 1966, 27). Efterfølgende har en række studier vist, at partiledere spiller en væsentlig rolle for valgresultatet, og at især vælgernes opfattelse af ledende kandidaters kompetence, integritet og troværdighed er vigtige faktorer (se f.eks. Clarke et al. 2004, Funk 1997, Kinder et al. 1980, Hayes 2009, Stevens \& Karp 2012). Andre studier viser dog, at der måske nok er en betydning af politiske lederes personlighed, men at den enten er relativt begrænset - eksempelvis som følge af institutionelle faktorer såsom valgsystem og styreform (parlamentarisme vs. præsidentialisme) - eller at den ligefrem er tvivlsom (Jenssen \& Aalberg 2006, King 2002).

Jeg vil i denne artikel argumentere for, at den uklare betydning af kandidaters personlighed i hidtidige resultater kan have en teoretisk såvel som en metodisk årsag. Teoretisk er betydningen af kandidatpersonlighed oftest - f.eks. i de danske valgundersøgelser - undersøgt ved at bede respondenter indikere deres sympati for eksempelvis Helle Thorning-Schmidt og Lars Løkke Rasmussen samt vurdere politikerne på personlighedstræk som kompetence, intelligens og troværdighed (se f.eks. Andersen \& Borre 2007, Hansen \& Andersen 2013, Hayes 2009, Funk 1997). Imidlertid giver disse træk ikke mulighed for at undersøge, om forskellige vælgere foretrækker forskellige kandidatpersonligheder, fordi vælgerne generelt set må forventes at foretrække kompetente, intelligente og troværdige kandidater (se f.eks. Kinder et al. 1980, Funk 1997). I denne artikel trækker jeg på to grupper af forskningsresultater, som hver især viser, at vælgerne har forskellige forventninger til kandidaters personlighed afhængigt af kandidaternes partifarve (Hayes 2005, Goren 2002, 2007), og at venstre- og højreorienterede individer har fundamentalt forskellige opfattelser af den sociale verden (Hibbing et al. 2013, Caprara et al. 2003, Duckitt \& Sibley 2010, Carney et al. 2008). Ud fra dette kan det forventes, at venstre- og højreorienterede vælgere også vil foretrække forskellige kandidatpersonligheder. Konkret forventer jeg, at en dominant og kompromisløs personlighed foretrækkes mere blandt højre- end blandt venstreorienterede individer, og at en venlig og imødekommende personlighed omvendt foretrækkes mere på venstre- end på højrefløjen.

Metodisk set giver klassiske survey-undersøgelser baseret på observationelle tværsnitsdata simpelthen ikke mulighed for at isolere en direkte kausaleffekt af kandidaters personlighed på hverken kandidaters elektorale succes eller på, hvor godt vælgerne vurderer kandidaterne. Dette skyldes, at respondenterne i disse undersøgelser foruden indtryk af kandidaternes personlighed også kender disses holdninger og ikke mindst partifarve. Personlighedsvurderingerne kan dermed ikke rimeligt antages at være uafhængige af disse andre faktorer, hvorfor Venstrevælgere formentlig vil tendere til at vurdere Lars Løkke Rasmussen mere positivt end Helle Thorning-Schmidt på samtlige personlighedsdimensioner og vice versa for socialdemokratiske vælgere. Med andre ord er kausalrelationen i observationalle tværsnitsstudier mellem overordnet sympati med en kandidat og dennes mere specifikke personlighedstræk såsom kompetence, imødekommenhed og dominans langt fra entydig. Jeg søger at komme dette endogenitetsproblem til livs ved at benytte et eksperimentelt design, hvori deltagerne tilfældigt tildeles én af to beskrivelser af en fiktiv politiker, som kun varierer med hensyn til den beskrevne personlighed.

Herunder fremføres først, hvorfor der er gode teoretiske grunde til at forvente, at vælgerne på henholdsvis venstre- og højrefløjen vil have forskellige præferencer for kandidatpersonligheder. Derefter behandler metodeafsnittet, hvordan eksperimentet løser problemet med at isolere en elektoral effekt af kandidatpersonlighed.

\section{Fundamentale forskelle mellem højre og venstre}

Den eksisterende valglitteratur viser som nævnt, at vælgerne generelt præmierer de kandidater, der opfattes som mest kompetente og troværdige. Imidlertid er der også to forskellige grupper af resultater, der skitserer en mere nuanceret betydning af kandidaters personlighed, og som 
giver anledning til at forvente, at venstre- og højreorienterede kandidater vil foretrække forskellige kandidatpersonligheder.

For det første viser Hayes (2005), hvordan partiernes issue ejerskaber kan have spill-over-effekter og skabe 'trait ownerships', som konkret giver sig udtryk i en forventning om, at republikanske kandidater er stærkere ledere og mere moralske end demokraternes kandidater, der omvendt forventes at være mere medfølende og empatiske. Goren (2007) bygger videre på dette fund og viser, at vælgere, der sympatiserer med enten demokraterne eller republikanerne, er tilbøjelige til at straffe modstanderpartiets præsidentkandidat med særligt negative vurderinger på de personlighedstræk, som deres egen kandidat har ejerskab af. Med andre ord tenderer demokrater til at vurdere republikanske præsidentkandidater særligt negativt på medfølelse og empati - og vice versa for republikanske vælgeres vurderinger af demokratiske kandidater på lederskab og moral.

Hvor Hayes og Goren fokuserer på forventninger til kandidaterne, tager andre forskere udgangspunkt $\mathrm{i}$ vælgernes prædispositioner og viser, at venstre- og højreorienterede individer på en lang række måder er fundamentalt forskellige. En efterhånden omfattende litteratur viser, at individer på de to fløje kan beskrives med vidt forskellige personlighedsprofiler ud fra den såkaldte Big Five-personlighedsmodel: Venstreorienterede tenderer til at være åbne over for nye indtryk (Openness) samt at være venlige og imødekommende (Agreeableness), mens højreorienterede omvendt er karakteriseret ved at være samvittighedsfulde, pligtopfyldende (Conscientiousness) og $i$ et vist omfang mere extroverte (for oversigtsartikler se f.eks. Carney et al. 2008, Mondak \& Hibbing 2012, Caprara \& Vecchione 2013). I forlængelse heraf finder Caprara og kolleger, at politikere og vælgere inden for en given fløj tenderer til at have ens og kongruente personlighedsprofiler (Caprara et al. 2003, Caprara \& Vecchione 2013). Forskning har desuden vist, hvordan basale forskelle mellem venstre- og højreorienterede individer er delvist forankrede i genetik og manifesterer sig i forskellig smag i forhold til mad, musik, boligindretning, nonverbale kommunikationsmønstre og reaktion i forhold til angstprovokerende stimuli (Alford et al. 2005, Hatemi et al. 2013, Carney et al. 2008, Oxley et al. 2008, Hibbing et al. 2013). På denne baggrund konkluderer Hibbing og kolleger, at venstre- ('liberals') og højreorienterede ('conservatives') "experience and process different worlds" (Hibbing et al. 2013, 114). Endelig uddybes og nuanceres dette i en række socialpsykologiske studier, som viser, at venstre- mere end højreorienterede individer tenderer til at opfatte den sociale verden som et sikkert, rart og behageligt sted præget af samarbejde og altruisme. Omvendt ser højreorienterede i større stil den sociale verden som konkurrencepræget og fokuserer på trusler i form af andre grupper samt normbrydere (Duckitt \& Sibley 2010, Jost et al. 2009).

Lederskab både i og uden for den politiske verden kan grundlæggende defineres som evnen til at koordinere aktiviteter med det formål at nå et fælles mål (Spisak et al. 2012). Sammen med de nævnte fundamentale forskelle i opfattelsen af den sociale verden mellem højre- og venstreorienterede individer, er det oplagt at forvente, at der også foretrækkes forskellige kandidatpersonligheder på de to fløje. Højreorienterede vælgere bør stemme på de kandidater, som de tror, er bedst til at sikre gruppen mod eksterne trusler samt overholdelsen af normer internt $i$ gruppen, mens venstreorienterede bør vælge kandidater, som kan facilitere og skabe samarbejdet internt i gruppen. En række eksperimentelle studier viser netop, at lederpræferencer afhænger af, hvilket problem man opfatter som vigtigst. Således foretrækker deltagerne i disse eksperimenter maskuline og dominant udseende ledere, når de får at vide, at deres gruppe er i konflikt eller ligefrem i krig med en anden gruppe. Tilsvarende vælger deltagerne feminine, mindre dominante og mere venligt udseende ledere, når der er fred, og de i stedet skal løse problemer internt i deres egen gruppe i form af eksempelvis et samarbejdsproblem mellem gruppens medlemmer (Little et al. 2007, Spisak et al. 2012, Laustsen \& Petersen 2013). Imidlertid er der i en politisk sammenhæng sjældent et klart defineret problem, som alle vælgere prioriterer som det vigtigste. Derfor bør vi forvente, at individer på en dagligdags basis i fraværet af klart definerede problemer vil basere deres lederpræferencer på deres fundamentale opfattelse af den sociale verden (og de problemer denne opfattelse giver anledning til) udtrykt ved deres ideologiske prædisposition. Helt konkret forventer jeg derfor, at højreorienterede individer, som ser verden som et konkurrencepræget og farligt sted, vil vurdere en dominant og kompromisløs kandidatpersonlighed mere positivt end venstreorienterede individer. Omvendt forventer jeg, at venstreorienterede individer, som ser verden som et sikkert og samarbejdende sted, vil vurdere en imødekommende kandidatpersonlighed mere positivt end højreorinterede individer.

\section{Forskningsdesign og metode}

Ovenstående forventning om at præferencer for kandidaters personlighed varierer med ideologisk prædisposition bliver testet med et surveyeksperiment gennemført blandt danske studerende. Det eksperimentelle design er helt centralt i bestræbelserne på at undersøge betydningen af kandidatpersonlighed, uden at denne kan være påvirket af forudgående holdninger til kandidatens politiske hold- 
ninger, partifarve eller andre specifikke karakteristika knyttet til denne. I den seneste danske valgundersøgelse forsøger man, at komme dette problem til livs ved at undersøge sammenhængen mellem respondentens sympati for en given partileder og respondentens stemmeadfærd under samtidig kontrol for respondentens sympati for partilederens parti (Hansen \& Andersen 2013). Imidlertid finder forfatterne selv, at sympati med Johanne Schmidt-Nielsen ikke havde nogen signifikant effekt på sandsynligheden for at stemme på Enhedslisten, fordi „partisympati og ledersympati er så snavert forbundet, at man ved at fjerne effekten af partisympati gor det umuligt at vise den positive effekt, Johanne Schmidt-Nielsen har for Enhedslisten" (Hansen \& Andersen 2013, 204).

For at komme dette problem til livs benytter jeg her et eksperimentelt design, hvor eksperimentets deltagere præsenteres for én af to beskrivelser af en fiktiv politiker uden partifarve og uden at få oplyst kandidatens politiske holdninger. Eksperimentet giver mig først og fremmest fuldstændig kontrol over den uafhængige variabel, kandidatpersonlighed. Ved kun at variere faktorer knyttet til kandidatpersonlighed kan jeg være sikker på, at en eventuel forskel i hvor godt eksperimentets deltagere synes om kandidaten, alene kan tilskrives den beskrivelse af kandidatens personlighed, som de har læst. Den eksperimentelle logik sikrer også, at jeg kan være sikker på, at det er kandidatens personlighed, som har påvirket deltageren til at synes godt om kandidaten. I virkelighedens politiske verden, kan man ikke umiddelbart afvise den modsatte historie: At en vælger stemmer på en given politisk kandidat (eksempelvis fordi vælgeren traditionelt stemmer på kandidatens parti) og bagefter indoptager positive holdninger til kandidaten for at retfærdiggøre sin valghandling (Lenz 2009, Lenz 2012).

Eksperimentet er dog ikke uden ulemper, idet virkelighedens kandidater jo netop kendes i samspil med deres partifarve, holdninger og meget andet. Hvis jeg i dette studie derfor finder en betydning af kandidaters personlighed, kan resultatet derfor næppe tages som udtryk for andet, end at forskellige vælgere faktisk foretrækker forskellige kandidatpersonligheder, når kandidaten er relativt ukendt. Hvor meget dette betyder uden for den eksperimentelle kontekst, samt hvor stor den relative betydning af kandidatpersonlighed er i forhold til eksempelvis partifarve, vil fortsat være uklart. Pointen er derfor, at eventuel støtte til den opstillede forventning ikke vil kunne generaliseres til mere end, at kandidatpersonlighed altså $i$ sig selv kan påvirke, hvor godt vælgerne synes om en kandidat, hvilket dog med de uklare og divergerende resultater i den nuværende litteratur in mente potentielt vil besvare et vigtigt spørgsmål (se Petersen et al. (2007)) for en generel diskussion af fordele og ulemper ved eksperimenter).

\section{Eksperimentel manipulation af kandidatpersonlighed}

Alle deltagerne i eksperimentet læste en kort tekst om en fiktiv mandlig politiker, Christian Mortensen. Indledningsvist blev Christian Mortensen beskrevet som en kompetent og hårdtarbejdende politiker for alle eksperimentets deltagere. Men efter denne fælles præsentation varieredes beskrivelsen, så en tilfældigt udvalgt halvdel af eksperimentets deltagere blev præsenteret for en imødekommende kandidatpersonlighed, mens den anden halvdel præsenteredes for en dominant kandidatpersonlighed. Det er vigtigt at understrege, at det eneste, som blev varieret mellem de to beskrivelser, er aspekter relateret til kandidatens personlighed. Kandidaten hedder således det samme i begge beskrivelser, og partitilknytning forbliver ligeledes ukendt for alle respondenter. For at undgå at kandidatens navn skulle påvirke, hvordan eksperimentets deltagere lod sig påvirke af personlighedsbeskrivelsen, blev et helt almindeligt navn, Christian Mortensen, benyttet. Tabel 1 gengiver ordlyden for beskrivelserne af Christian Mortensen i eksperimentet:

Tabel 1: Beskrivelser af den fiktive kandidat, Christian Mortensen, i eksperimentet.*

\begin{tabular}{|c|c|}
\hline \multicolumn{2}{|l|}{ Fælles introduktion } \\
\hline \multicolumn{2}{|c|}{$\begin{array}{l}\text { Christian Mortensen er kendt som et arbejdsomt og resultatorienteret folketingsmedlem. Han har hele vejen gennem sin politiske karriere både taget initiativ til } \\
\text { lovgivningsarbejde og fulgt det til dørs gennem seriøsitet i folketingsudvalgene. }\end{array}$} \\
\hline Imødekommende beskrivelse & Dominant beskrivelse \\
\hline $\begin{array}{l}\text { Blandt sine politiske venner er Christian Mortensen kendt som en indlevende } \\
\text { forhandler, der på en fornuftig måde behersker det politiske spil og for- } \\
\text { mår at skabe aftaler og samarbejder. Blandt sine politiske modstandere } \\
\text { anses han tilsvarende for at være en person, der aldrig „tromler“ andre } \\
\text { ned under hverken forhandlinger eller udvalgsarbejde. I den seneste tid har } \\
\text { Christian Mortensen tilmed udviklet sig til en særdeles fremtrædende skikkelse } \\
\text { i sin folketingsgruppe, som stort set alle har det godt med at henvende } \\
\text { sig til. }\end{array}$ & $\begin{array}{l}\text { Blandt sine politiske venner er Christian Mortensen kendt som en skrap for- } \\
\text { handler, der formår at skabe resultater ved nærmest urokkeligt at stå } \\
\text { fast på sin folketingsgruppes politik. Blandt sine politiske modstandere } \\
\text { anses han tilsvarende for at være en hård negl, der ofte tager styringen } \\
\text { i forhandlinger og udvalgsarbejdet. I den seneste tid har Christian Mortensen } \\
\text { tilmed udviklet sig til en særdeles fremtrædende skikkelse i sin folketingsgruppe, } \\
\text { som de færreste har lyst til at lægge sig ud med. }\end{array}$ \\
\hline
\end{tabular}

* Markeringer med fed og kursiv skrift indikerer forskellene mellem de to beskrivelser. 


\section{Eksperimentets gennemforelse}

Eksperimentet blev gennemført som et traditionelt surveyeksperiment med 266 studerende ved Aarhus Universitet (132 kvinder). Først besvarede deltagerne en række spørgsmål om sig selv og deres politiske holdninger samt angav deres placering på en politisk ideologisk skala fra $0-10$, som i analyserne omkodes til en 0-1-skala, hvor ' 0 ' angiver den mest venstreorienterede position og ' 1 ' tilsvarende den mest højreorienterede position (gns. $=0,487$, std. afv. 0,232). Dernæst blev deltagerne tilfældigt tildelt enten den imødekommende eller den dominante personlighedsbeskrivelse af Christian Mortensen (se evt. tabel 1). Efter at have læst personlighedsbeskrivelsen vurderede deltagerne kandidatens personlighed på en række relevante dimensioner - såsom bl.a. imødekommenhed og dominans - for at undersøge, om de to personlighedsbeskrivelser varierede som forventet. Til slut angav deltagerne på et såkaldt 'følelsestermometer', hvor godt de overordnet synes om den beskrevne kandidat. Deltageren blev konkret bedt om at angive en værdi mellem ' 0 ' og '100' på følelsestermometeret. Denne skala omkodes også til en 0-1 skala, hvor ' 0 ' angiver, at deltageren 'overhovedet ikke bryder sig om kandidaten', '0,5' angiver, at deltageren 'hverken synes godt eller skidt om kandidaten', og endelig angiver ' 1 ', at deltageren 'synes rigtig godt om kandidaten' (gns. = 0,703; std. afv. 0,169).

\section{Resultater}

I den følgende analyse er deltagernes ideologiske selvplacering og deres vurderinger af Christian Mortensen omkodet til 0-1 skalaer. ' 1 ' repræsenterer således den mest højreorienterede ideologiske position, den mest dominante eller imødekommende vurdering på personlighed og endelig den mest positive vurdering af Christian Mortensen på følelsestermometeret. Den eksperimentelle betingelse - om Christian Mortensen er beskrevet som hhv. dominant (kodet ' 0 ' og udgør referencekategorien) eller imødekommende (kodet ' 1 ') - inddrages som en dikotom variabel.

For at teste, om de to forskellige beskrivelser af Christian Mortensen førte til de forventede forskelle i personlighedsopfattelse, udføres først et manipulationstjek. T-tests af forskellene i deltagernes opfattelse af Christian Mortensen med hensyn til dominans og imødekommenhed viser, at den dominante beskrivelse også er opfattet som signifikant mere dominant end den imødekommende beskrivelse $(t=21,736, \mathrm{P}<0,001)$. Tilsvarende er den imødekommende beskrivelse opfattet som signifikant mere imødekommende end den dominante beskrivelse $(\mathrm{t}$ $=-21,911, \mathrm{P}<0,001)$. Dette er også illustreret i Figur 1 .
Figur 1: Manipulationstjek for den imødekommende og dominante beskrivelse af den fiktive kandidat, Christian Mortensen.

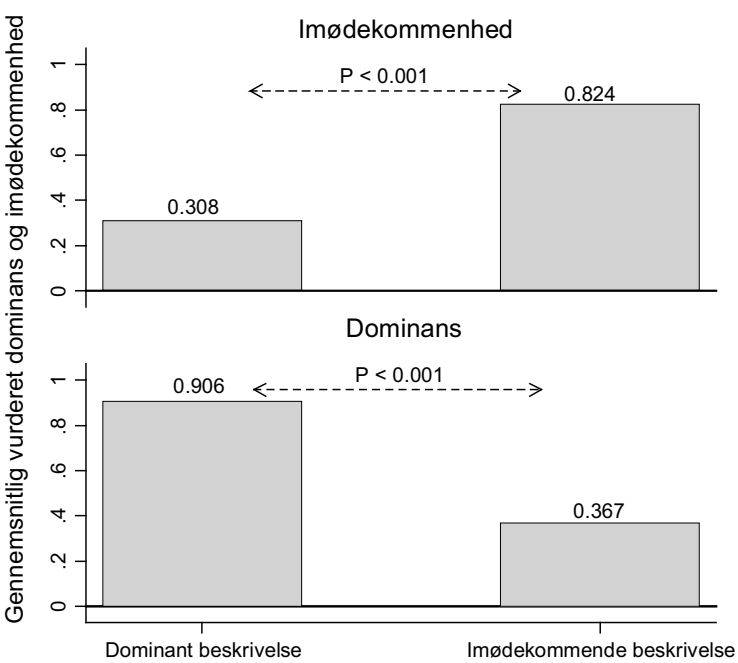

Søjlerne viser gennemsnitlige vurderinger af de to personlighedsbeskrivelser på 0-1 skalaer for hhv. dominans og imødekommenhed (' 1 ' angiver den størst mulige værdi). Det øverste panel viser vurderinger af imødekommenhed, mens det nederste panel viser vurderinger af dominans. Inden for hvert panel angiver den venstre søjle vurderingen for den dominante beskrivelse, mens den højre søjle viser vurderingen for den imødekommende beskrivelse. P-værdier er for t-tests af om vurderingerne af de to beskrivelser er signifikant forskellige.

Alt i alt har de to personlighedsbeskrivelser ført til den tilsigtede forskel i opfattelse af Christian Mortensen. Spørgsmålet er derfor nu, om deltagerne afhængigt af deres ideologiske prædisposition vil angive forskellig vurdering af Christian Mortensen på det benyttede følelsestermometer. Mere præcist forventes det, at højreorienterede individer vil foretrække en dominant og kompromisløs kandidatpersonlighed mere end venstreorienterede individer. Disse vil på den anden side foretrække en imødekommende og venlig kandidatpersonlighed mere end højreorienterede. Den dominante og imødekommende beskrivelse af Christian Mortensen udgør eksperimentets to betingelser, og derfor bør vi baseret på den generelle teoretiske formodning forvente, at deltagerne angiver mere positive vurderinger for den dominante beskrivelse af Christian Mortensen, i takt med at deres ideologiske prædisposition bliver mere højreorienteret. Omvendt bør vi for den imødekommende beskrivelse af Christian Mortensen finde, at vurderingerne bliver mindre positive i takt med stigende højreorientering - svarende til at vurderingen bliver mere positiv med stigende venstreorientering. Med andre ord er den centrale test af den opstillede forventning, om den tilfældigt tildelte beskrivelse af 
Christian Mortensen som hhv. dominant (referencekategori) eller imødekommende interagerer med deltagernes politiske ideologi. Resultatet er en model, der forudsiger deltagernes overordnede vurdering af Christian Mortensen ved beskrivelsen af Christian Mortensen, deltagernes politiske ideologi og interaktionen mellem beskrivelse og ideologi som vist i Tabel 2 nedenfor.

Modellen viser effekterne af personlighedsbeskrivelsen af Christian Mortensen, politisk ideologi samt interaktionen mellem personlighedsbeskrivelse og ideologi på deltagernes overordnede vurdering af Christian Mortensen. Personlighedsbeskrivelsen er en dikotom variabel, hvor den dominante beskrivelse udgør referencekategorien og er kodet ' 0 ', mens den imødekommende beskrivelse er kodet ' 1 '. Modellen rapporterer ustandardiserede regressionskoefficienter fra en OLS-regression med standardfejl i parentes.

Tabel 2: Forudsigelse af overordnet vurdering af Christian Mortensen

\begin{tabular}{|l|l|}
\hline $\begin{array}{l}\text { Personlighedsbeskrivelse } \\
\text { Imødekommende beskrivelse }\end{array}$ & $\begin{array}{l}0.256^{\star \star \star} \\
(0.043)\end{array}$ \\
\hline Politisk ideologi & $0.133^{\star}$ \\
& $(0.056)$ \\
\hline Personlighedsbeskrivelse ${ }^{\star}$ politisk & $-0.216^{\star \star}$ \\
ideologi & $(0.079)$ \\
\hline Konstant & $0.564^{\star \star \star}$ \\
& $(0.031)$ \\
\hline $\mathrm{N}$ & 258 \\
\hline $\mathrm{R}^{2}$ & 0.228 \\
\hline
\end{tabular}

Note: Overordnet vurdering af Christian Mortensen er målt på en 0-1 skala, hvor 1 angiver den mest positive vurdering af Christian Mortensen. Politisk ideologi er målt på en 0-1 skala, hvor 1 angiver den mest højreorienterede position.

${ }^{\dagger} \mathrm{p}<0.10 ;{ }^{*} \mathrm{p}<0.05 ;{ }^{* *} \mathrm{p}<0.01 ;{ }^{* * *} \mathrm{p}<0.001$. Tabellens $\mathrm{p}$-værdier er baseret på tosidede hypotesetests.

Som det fremgår af Tabel 2, er interaktionen mellem personlighedsbeskrivelse og ideologi signifikant. For at få et mere nuanceret billede af hvad interaktionen egentlig dækker over, viser Figur 2 effekten af politisk ideologi på den overordnede vurdering af Christian Mortensen for både den dominante (til venstre) og den imødekommende (til højre) beskrivelse af Christian Mortensen. Barerne i Figur 2 viser derfor regressionskoefficienten for sammenhængen mellem ideologi og overordnet vurdering af Christian Mortensen for hhv. den dominante (til venstre) og den imødekommende personlighedsbeskrivelse (til højre).

Søjlerne viser effekten af respondenternes ideologi på deres overordnede vurdering af den fiktive kandidat, Christian Mortensen, når denne er beskrevet som hhv. dominerende (til venstre) og imødekommende (til højre). Barerne er ustandardiserede regressionskoefficienter og de stiplede linjer indikerer 90 procent konfidensintervaller.

\section{Figur 2: Effekter af politisk ideologi på overordnet vurdering af} Christian Mortensen

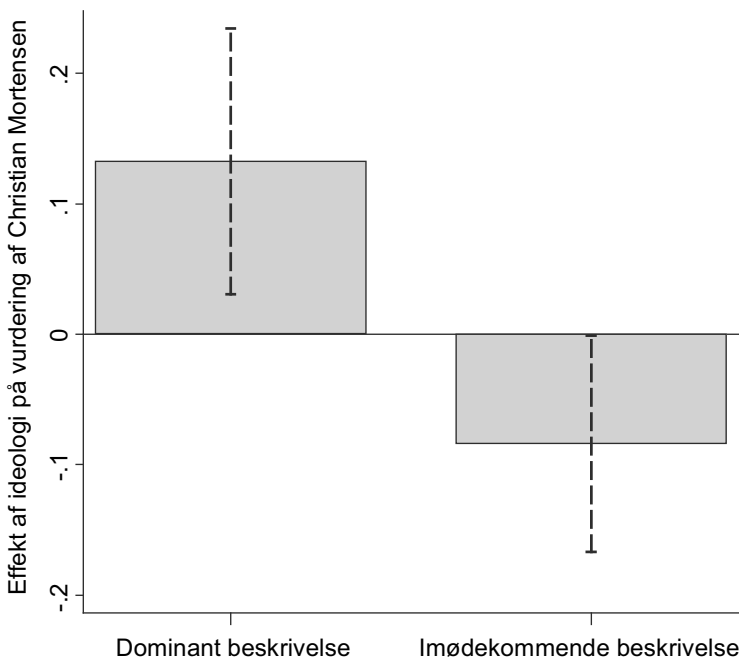

Note: Respondenterne blev tilfeldigt tildelt enten den imødekommende eller den dominante personlighedsbeskrivelse af Christian Mortensen.

Som det fremgår af Figur 2, er der for den dominante personlighedsbeskrivelse en positiv sammenhæng mellem politisk ideologi, og hvor godt deltagerne synes om Christian Mortensen $(b=0,133, p=0,033)$. Dette betyder, at de mest højreorienterede vælgere (dem, der scorer 1 på ideologi) synes 13,3 procentpoint bedre om den dominante beskrivelse af Christian Mortensen end de mest venstreorienterede deltagere (de, der scorer 0 på ideologi). Med andre ord synes deltagerne bedre og bedre om Christian Mortensen, jo mere højreorienterede de er. Omvendt findes der for den imødekommende beskrivelse en negativ sammenhæng mellem politisk ideologi og overordnet vurdering af Christian Mortensen $(b=-0,084, p=$ $0,096),{ }^{1}$ således at de mest højreorienterede synes 8,4 procentpoint dårligere om den imødekommende beskrivelse af Christian Mortensen end de mest venstreorienterede. Altså kan deltagerne lide Christian Mortensen mindre og mindre i takt med, at de bliver mere højreorienterede - eller de kan lide ham mere og mere i takt med, at de bliver mere venstreorienterede. De omtalte effekter kan dog siges at være kunstige, idet de sammenligner de absolutte yderpunkter på den politisk ideologiske skala. For at vurdere effekten af en „realistisk“ forskel i ideologi kan man i stedet basere sin beregning på den såkaldte interkvartile afstand i ideologi - altså en sammenligning af deltagerne, som henholdsvis markerer den 25. og den 
75. percentil for ideologivariablen. Den 25. percentil kan forstås som en moderat venstreorienteret deltager, mens den 75. percentil tilsvarende kan forstås som en moderat højreorienteret deltager. Ved at bruge den estimerede model til at beregne, hvor forskelligt de to moderate deltagere fra hver sin ende af det ideologiske spektrum synes om henholdsvis den dominante og den imødekommende beskrivelse af Christian Mortensen, fås et mere realistisk indtryk af forskellige vælgeres præferencer for politiske personligheder. Sådan en beregning viser, at den moderat højreorienterede deltager synes 5,2 procentpoint bedre om den dominerende beskrivelse af Christian Mortensen, men 3,4 procentpoint dårligere om den imødekommende beskrivelse sammenlignet med den moderat venstreorienterede deltager. Disse forskelle er naturligt nok ikke så store, som når de politisk ideologiske endepunkter sammenlignes, men dog stadig af substantiel interesse.

Samlet set finder den opstillede forventning dermed opbakning: For den fiktive kandidat Christian Mortensen findes, at den dominante beskrivelse af hans personlighed bliver vurderet signifikant mere positivt blandt højreorienterede end venstreorienterede deltagere. Omvendt vurderer de venstreorienterede deltagere den imødekommende personlighedsbeskrivelse signifikant mere positivt end højreorienterede deltagere. Dog fremgår det også af Figur 2, at effekten af ideologi på vurdering af Christian Mortensen er stærkere for den dominante end den imødekommende personlighedsbeskrivelse.

\section{Diskussion og konklusion}

Eksperimentets resultat er både interessant i lyset af den eksisterende valgforskning og i en politisk psykologisk sammenhæng. I forhold til valgforskningen taler resultatet til debatten om, hvorvidt kandidaters personligheder overhovedet spiller en rolle for valgresultatet, og i en politisk psykologisk forstand giver resultatet indblik i den psykologi, som ligger bag vurderinger og valg af forskellige politiske personligheder.

I relation til valgforskningen viser eksperimentet, at kandidaters personlighed faktisk kan spille en rolle for vælgernes kandidatpræferencer. Imidlertid er dette en anden rolle end den, som typisk er blevet undersøgt i den eksisterende litteratur. Her skelnes sjældent mellem forskellige kandidatpersonligheder, og i stedet undersøges, om vælgernes vurderinger af ledende kandidaters sympati, kompetence, intelligens og troværdighed påvirker, hvem de stemmer på. Med andre ord har den eksisterende valglitteratur ledt efter én type af kandidatpersonlighed, som implicit antages at være universelt vindende. Eksperimentets resultat siger umiddelbart ikke noget om, hvorvidt sådan en effekt eksisterer eller ej. Men det viser til gengæld, at man overser en væsentlig betydning af kandidatpersonlighed, hvis man kun fokuserer på personlighedstræk, som alle vælgere uanset ideologisk prædisposition skal synes om. Hvis fremtidige valgundersøgelser fortsat vil forfølge spørgsmålet om betydningen af kandidaters personlighed, vil det i lyset af eksperimentets resultat være hensigtsmæssigt at inkludere et mere varieret batteri af karakteristika til beskrivelse af kandidatpersonlighederne. Ved at analysere betydningen af disse i samspil med respondenternes ideologiske prædisposition vil det være muligt at undersøge, om mønstre svarende til det, som jeg har fundet i denne artikel, kan genfindes for virkelige valg, selv når kandidaters partifarve og holdninger er kendt.

Eksperimentets resultat relaterer sig også direkte til den voksende litteratur om fundamentale forskelle i verdensanskuelse og personlighedsprofil mellem højre- og venstreorienterede individer. Tidligere er denne forskel blevet knyttet sammen med forskellige præferencer og livsstile udtrykt ved eksempelvis indretning, musiksmag og kropssprog (Alford et al. 2005, Hatemi et al. 2007, Duckitt \& Sibley 2010, Carney et al. 2008, Oxley et al. 2008, Hibbing et al. 2013). At højreorienterede individer mere end venstreorienterede værdsætter en dominant kandidatpersonlighed, og at det modsatte gør sig gældende med hensyn til en imødekommende kandidatpersonlighed, kan derfor ses som endnu en brik i det puslespil, som afdækker, hvordan politisk ideologi har omfattende og væsentlige konsekvenser for præferencer og holdninger i såvel politisk som i en bredere forstand. Resultatet giver dog også anledning til en række opfølgende spørgsmål. Tilsyneladende er der en større effekt af politisk ideologi på vurderingen af den dominante end den imødekommende kandidatpersonlighed. Det kunne være udtryk for, at kandidaters potentielle dominante personlighed udløser større opsplitning blandt vælgerne, end en imødekommende kandidat tilsvarende gør. En måde, hvorpå det kunne undersøges, om kandidat-dominans generelt er en stærkere ideologisk opdeler end kandidat-imødekommenhed, er ved at gennemføre et tilsvarende eksperiment i lande med væsentligt forskellige institutionelle indretninger som eksempelvis et præsidentielt styre med færre partier og kandidater. Dette ville potentielt kaste lys over generaliserbarheden af eksperimentets resultat. Fremtidige studier bør også undersøge, om og i givet fald hvordan præferencer for kandidatpersonlighed ændrer sig under klare kontekstuelle betingelser. Ved at indbygge en kontekstuel dimension i eksperimentet, som enten primer deltagerne med et samarbejdsproblem internt i deres egen gruppe eller et konfliktproblem mellem deres og en anden gruppe, vil de psykologiske mekanismer, som styrer højre- og venstreorienteredes kandidatpræferencer, potentielt blive belyst mere dybdegående. 
Endelig er det værd at fremhæve implikationerne af eksperimentets resultater i forhold til et valgsystem som det danske, der er karakteriseret ved relativt mange partier, som hver især opstiller en liste med mange kandidater i hver enkelt valgkreds. Med andre ord har vælgerne mulighed for at vælge ikke blot mellem partier, men også mellem politikere, som derved konkurrerer om vælgernes gunst med kandidater fra både andre partier og deres eget parti. Undersøgelser viser, at danske vælgere sjældent går så vidt, at de skifter blok, men at de i højere grad skifter parti inden for den røde eller den blå blok (Hansen et al. 2007). Eksperimentets resultat giver for så vidt god mening i relation til denne konklusion, idet det jo netop viser, at en given politiker (og derfor nok også partileder) vil have svært ved at flytte vælgere fra den konkurrerende blok til sin egen. Dette skyldes, at vælgerne i den anden blok ønsker en fundamentalt anderledes kandidatpersonlighed end vælgerne i politikeres egen blok. I stedet støtter resultatet, at kandidatpersonlighed meget vel kan flytte stemmer mellem partier, som deler ideologisk arvegods, eller mellem kandidater, som ligefrem deler partimedlemskab. Forklaringen er igen, at vælgere i samme blok har nogenlunde sammenfaldende politisk ideologi og verdensanskuelse og derfor i større grad ønsker den samme type politiker end vælgere i hver sin blok.

Den danske valgforskning har udelukkende fokuseret på betydningen af partiledere og typisk også været mest optaget af, om disse kan flytte stemmer på tværs af den politiske midte. Til gengæld har der været langt mindre opmærksomhed rettet mod, hvorvidt kandidatpersonlighed kan flytte rundt på stemmerne mellem partierne inden for en given politisk blok. Med udgangspunkt i litteraturen om dybtliggende forskelle mellem højre- og venstreorienterede individer bidrager dette eksperiments resultat til at forklare vælgervandringer mellem partier i samme blok (som eksempelvis Villy Søvndahls positive effekt på SF i 2007, og Lars Barfoed negative ditto for de Konservative i 2011). Men resultatet åbner yderligere op for, at ikke kun partilederes, men også mindre profilerede kandidaters personlighed kan være væsentlig at beskæftige sig med i forbindelse med danske og udenlandske valg. Danske vælgere står nemlig ofte over for et valg mellem en række kandidater opstillet i deres kreds, hvoraf ingen er decideret spydspids for vælgerens foretrukne parti. I sådan en situation kan eksperimentets resultat fortolkes således, at venstreorienterede vælgere formentlig vil foretrække den af de opstillede kandidater, som de opfatter som den mest imødekommende (opstillet for det parti, som de traditionelt identificerer sig med). Højreorienterede vælgere vil tilsvarende tendere til at vælge den af de opstillede kandidater, som de opfatter som mere kompromisløs og dominant.

\section{Litteratur}

Alford, J, C Funk \& J Hibbing 2005, 'Are Political Orientations Genetically Transmitted?', American Political Science Review, vol. 99, no. 2, pp. 153-67.

Andersen, J \& O Borre 2003, 'Personfaktorer', in JG Andersen \& O Borre (red.) Politisk Forandring, Systime Academic, Århus.

Andersen, J \& O Borre 2007, 'Partiledere gør en forskel', in JG Andersen, J Andersen, O Borre, KM Hansen \& HJ Nielsen (red.), Det Nye Politiske Landskab, Academica, Århus.

Caprara, GV, C Barbaranelli, C Consiglio, L Picconi \& PG Zimbardo 2003, 'Personalities of politicians and voters: Unique and synergistic relationships', Journal of Personality and Social Psychology, vol. 84, no. 4, pp. 849-856.

Caprara, GV \& M Vecchione 2013, 'Personality Approaches to Political Behavior', in L Huddy, DO Sears \& JS Levy (red.), The Oxford Handbook of Political Psychology, 2. edn., Oxford University Press: Oxford.

Carney, DR, JT Jost, SD Gosling \& Jeff Potter 2008, 'The Secret Life of Liberals and Conservatives: Personality Profiles, Interaction Styles, and the Things They Leave Behind', Political Psychology, vol. 29, no. 6, pp. 807-840.

Clark, HD, D Sanders, MC Stewart \& P Whiteley 2004, Political Choice in Britain, Oxford University Press: Oxford.

Danmarks Statistik 2012, Statistisk Årbog 2012, Danmarks Statistik, København: http://www.dst.dk/pukora/epub/upload/16252/ saa2012.pdf

Duckitt, J \& CG Sibley 2010, 'Personality, Ideology, Prejudice, and Politics: A Dual-Process Motivational Model', Journal of Personality, vol. 78, pp. 1861-94.

Funk, CL 1997, 'Implications of Political Expertise in Candidate Trait Evaluation', Political Research Quarterly, vol. 50, no. 3, pp. 675-697.

Funk, CL 1999, 'Bringing the candidate into models of candidate evaluation', Journal of Politics, vol. 61, pp. 700-720.

Goren, P 2002, 'Character Weakness, Partisan Bias, and Presidential Evaluation', American Journal of Political Science, vol. 46, no. 3, pp. 627-641.

Goren, P 2007, 'Character Weakness, Partisan Bias, and Presidential Evaluation: Modifications and Extensions', Political Behavior, vol. 29, no. 3, pp. 305-325.

Hansen, KM, R Slothuus \& C de Vreese 2007, 'Man har et parti, indtil man finder et nyt: Portræt af vælgeren, som skiftede parti', in JG Andersen, J Andersen, O Borre, KM Hansen \& HJ Nielsen (red.), Det Nye Politiske Landskab, Academica, Århus.

Hansen, KM \& JG Andersen 2013, 'En samlet model for partivalg', in R Stubager, KM Hansen \& JG Andersen, Krisevalg, Økonomien og Folketingsvalget 2011, Jurist- og Økonomforbundets Forlag, København.

Hatemi, PK, SE Medland, KI Morley, AC Heath \& NG Martin 2007, 'The Genetics of Voting: An Australian Twin Study', Behavioral Genetics, vol. 37, no. 435-48.

Hayes, D 2005, 'Candidate Quality through a Partisan Lens: A Theory of Trait Ownership', American Journal of Political Science, vol. 49, no. 4, pp. 908-923.

Hayes, D 2009, 'Has Television Personalized Voting Behavior?', Political Behavior, vol. 31, pp. 231-260.

Hibbing, JR, KB Smith \& JR Alford 2013, Predisposed, Routledge, New York.

Jenssen, AT \& T Aalberg 2006, 'Party-leader effects in Norway: A multi-methods approach', Electoral Studies, vol. 25, pp. 248-269. 
Jost, JT, CM Federico \& JL Napier 2009, 'Political Ideology: Its structure, Functions, and Elective Affinities', Annual Review of Psycho$\log y$, vol. 60, pp. 307-33.

Kinder, DR, MD Peters, RP Abelson \& ST Fiske 1980, 'Presidential Prototypes', Political Behavior, vol. 2, no. 4, pp. 315-337.

King, A (red.) 2002, Leaders' Personalities and the Outcome of Democratic Elections, Oxford University Press, Oxford.

Laustsen, L \& MB Petersen 2013, 'Winning Faces Vary By Ideology: Evolutionary Psychology, Candidate Faces and Democratic Elections', Unpublished working paper.

Lenz, GS 2009, 'Learning and Opinion Change, Not Priming: Reconsidering the Priming Hypothesis', American Journal of Political Science, vol. 53, no. 4, pp. 821-837.

Lenz, GS 2012, Follow The Leader?, University of Chicago Press, Chicago.

Little, AC, RP Burriss, BC Jones \& SC Roberts 2007, 'Facial Appearance Affects Voting Decisions', Evolution and Human Behavior, vol. 28, pp. 18-27.

Mondak, JJ \& MV Hibbing 2012, 'Personality and Public Opinion', in AJ Berinsky (red.), New Directions in Public Opinion, Routledge, New York.
Oxley, D, KB Smith, JR Alford, MV Hibbing, JL Miller, MJ Scalora, PH Hatemi \& JR Hibbing 2008, 'Political Attitudes Vary with Physiological Traits', Science, vol. 321, no. 5896, pp. 1667-70.

Petersen, MB, R Slothuus, R Stubager \& L Togeby 2007, 'Eksperimenter: Et redskab i politologens værktøjskasse?’, Politica, vol. 39, no. 1, pp. 5-13.

Spisak, BR, PH Dekker, M Krüger \& MV Vugt 2012, 'Warriors and Peacekeepers: Testing a Biosocial Implicit Leadership Hypotheis of Intergroup Relations Using Masculine and Feminine Faces', PlosOne, vol. 7, no. 1, pp. 1-8.

Stevens, D \& JA Karp 2012, 'Leadership Traits and Media Influence in Britain', Political Studies, vol. 60, no. 4, pp. 787-808.

Stokes, DE 1966, 'Some Dynamic Elements of Contests for the Presidency', American Political Science Review, vol. 60, no. 1, pp. 19-28.

\section{Noter}

1. P-værdierne fra disse tests er fra separate OLS regressioner, der forudsiger overordnet vurdering af Christian Mortensen for hver personlighedsbeskrivelse, da interaktionsmodellen kun viser effekten af ideologi for de deltagere, der er blevet tildelt referencekategorien (den dominante beskrivelse af Christian Mortensen) på personlighedsvariablen. 